\title{
The Beyond Within: Grotto-Heavens (dongtian) in Taoist Ritual and Cosmology
}

Franciscus Verellen

\section{Citer ce document / Cite this document :}

Verellen Franciscus. The Beyond Within: Grotto-Heavens (dongtian) in Taoist Ritual and Cosmology. In: Cahiers d'ExtrêmeAsie, vol. 8, 1995. Mémorial Anna Seidel. Religions traditionnelles d'Asie orientale. Tome I. pp. 265-290;

doi : https://doi.org/10.3406/asie.1995.1096

https://www.persee.fr/doc/asie_0766-1177_1995_num_8_1_1096

Fichier pdf généré le 06/02/2019 


\section{Résumé}

Le contenu et le contexte taoïstes de la notion chinoise des "grottes-cieux" (dongtian) sont examinés ici au cours de la période de formation de cette notion, du IVe au Xe siècles de notre ère. Lieux de refuge, d'initiation et de passage transcendental, les microcosmes paradisiaques se trouvent à l'intérieur des montagnes sacrées. Le mot dong, littéralement "caverne" ou "torrent", signifie également "pénétrer", "communiquer" et "discerner".

Au sein de la géographie sacrée de la Chine, les grottes-cieux occupent, avec les Cinq Pics, une position primordiale. La cosmographie taoïste médiévale distingue deux séries de grottes-cieux, comprenant respectivement dix et trente-six lieux saints (cf. l'appendice). L'histoire des textes se référant aux dongtian suggère que l'origine de la notion est à placer dans le contexte des révélations du Shangqing des années 360 . Plus précisément, la visualisation du monde à part que constitue la grotte-ciel s'inscrirait, au premier abord, dans les pratiques méditatives suscitées par le mouvement scripturaire du Maoshan - pratiques qui avaient pour objet, à maints égards, une représentation intériorisée et spirituelle du monde physique.

La représentation de I 'univers comme grotte constitue de même une projection mentale de I 'espace rituel idéal : le modèle de I 'autel, de I 'oratoire, du sanctuaire qu'est le corps humain. A partir des Tang, cette conception se manifeste au grand public sous la forme du Jet du dragon, rite impérial qui permet au souverain d'entrer en communication avec le monde divin à travers les grottes. Les mêmes croyances magico-religieuses ayant trait aux microcosmes, à la re-création du monde en miniature, sous-tendent par ailleurs l'esthétique de la représentation des paysages en Chine.

Enfin sont abordés ici trois thèmes mythologiques évoqués par ces lieux de passage entre différents mondes : la grotte comme matrice, comme tombeau et comme paradis. La notion que I 'au-delà peut être contenu dans ce monde, voire à l'intérieur de chacun, suggère que l'imaginaire de la grotte-ciel puisse s'interpréter comme une démarche gnostique : la connaissance de la "véritable forme" (zhenxing) du monde physique devient ainsi à la fois une connaissance du soi et du chemin du salut. 


\title{
THE BEYOND WITHIN: GROTTO-HEAVENS (DONGTIAN 洞天) IN TAOIST RITUAL AND COSMOLOGY
}

\author{
Franciscus VERELLEN
}

Le contenu et le contexte taoistes de la notion chinoise des "grottes-cieux" (dongtian) sont examinés ici au cours de la période de formation de cette notion, du IVe au $X^{e}$ siècles de notre ère. Lieux de refuge, d'initiation et de passage transcendental, les microcosmes paradisiaques se trouvent à l'intérieur des montagnes sacrées. Le mot dong, littéralement "caverne" ou "torrent", signifie également "pénétrer", "communiquer" et "discerner".

Au sein de la géographie sacrée de la Chine, les grottes-cieux occupent, avec les Cinq Pics, une position primordiale. La cosmographie taoïste médiévale distingue deux séries de grottescieux, comprenant respectivement dix et trente-six lieux saints (cf. l'appendice). L'histoire des textes se référant aux dongtian suggère que l'origine de la notion est à placer dans le contexte des révélations du Shangqing des années 360 . Plus précisément, la visualisation du monde à part que constitue la grotte-ciel $s$ 'inscrirait, au premier abord, dans les pratiques méditatives suscitées par le mouvement scripturaire du Maoshan-pratiques qui avaient pour objet, à maints égards, une représentation intériorisée et spirituelle du monde physique.

La représentation de l'univers comme grotte constitue de même une projection mentale de l'espace rituel idéal : le modèle de l'autel, de l'oratoire, du sanctuaire qu'est le corps humain. A partir des Tang, cette conception se manifeste au grand public sous la forme du Jet du dragon, rite impérial qui permet au souverain d'entrer en communication avec le monde divin $\dot{a}$ travers les grottes. Les mêmes croyances magico-religieuses ayant trait aux microcosmes, à la re-création du monde en miniature, sous-tendent par ailleurs l'esthétique de la représentation des paysages en Chine.

Enfin sont abordés ici trois thèmes mythologiques évoqués par ces lieux de passage entre différents mondes : la grotte comme matrice, comme tombeau et comme paradis. La notion que l'audelà peut être contenu dans ce monde, voire à l'intérieur de chacun, suggère que l'imaginaire de la grotte-ciel puisse $s$ 'interpréter comme une démarche gnostique : la connaissance de la "véritable forme" (zhenxing) du monde physique devient ainsi à la fois une connaissance du soi et du chemin du salut.

Cahiers d'Extrême-Asie 8 (1995) : 265-290. 


\section{- ist denn das Weltall nicht in uns? \\ ... Nach Innen geht der geheimnisvolle Weg. \\ Novalis (1772-1801), Schriften II, 416-18.}

The grotto as a metaphor of the cosmos has a history in Europe as well as in China. On the shores of the Mediterranean Sea, grottocs had bcen cult sites since prehistoric times. For the Greeks of the age of Homer they werc places of refugc and of burial, sanctuaries of ancient mysteries, and oracles. The archetypal grotto was a source of holy wellsprings, inhabited by divine beings, yet not inaccessible to humans. Places of passage between worlds, these nymphaea were in time endowed with cosmic significance:

At the head of the harbor, there is an olive tree with spreading leaves, and nearby is a cave that is shaded, and pleasant, and sacred to the nymphs who are called the Nymphs of the Wellsprings, Naiads... and there is water forever flowing. It has two entrances, one of them facing the North Wind, where people can enter, but the one toward the South Wind has more divinity. That is the way of the immortals, and no men enter by that way.'

Fountain grottoes in Italian Renaissance gardens allude to this classical topos through a wealth of mythological conceits. Comparable references are found in Chinese gardens and container landscapes, as well as landscape painting, miniature carvings, and a variety of textual sources. The aesthetic principles underlying the depiction of grottoes and many other features of Chinese landscapes are of Taoist inspiration. ${ }^{2}$ This essay aims to explore the Taoist background and content of the Chinese notion of "grotto-heavens" in its formative period from the fourth to the tenth centuries. ${ }^{3}$

I will begin by outlining a few general aspects of the sacred mountain in the Taoist tradition which, though well known, may be useful in placing the Taoist vision of the grotto in its context. We shall then examine the development of grottoheavens in Taoist cosmography and their significance as the epitome of interiorized ritual space, before concluding with some remarks concerning mythological themes evoked by the notion of Heaven contained within the mountain.

' Homer, Odyssey 13.102-112; Richard Lattimore transl., The Odyssey of Homer (New York: Harper and Row, 1965), p. 201. See also the chapter "Metaphor of the Cosmos" in Naomi Miller, Heavenly Caves: Reflections on the Garden Grotto (New York: G. Braziller, 1982), pp. 13-28.

2 See Ellen Johnston Laing, "Caves, Clouds, and Terraces: Taoist Iconography in Chinese Landscape Depictions," unpublished paper for the conference "Mountains and the Cultures of Landscape," Santa Barbara, California, January 14-16, 1993, and Li Fengmao 李豐森, "Liuchao daojiao dongtian shuo yu youli xianjing xiaoshuo 六朝道教洞天説與遊歷仙境小説," Xiaoshuo xiqu yanjiu 小説战曲研究 1 (Taipei: Lianjing, 1988), pp. 3-52.

${ }^{3}$ The present article originated as a talk given at the "Sacred Mountains in Chinese Culture" symposium, Metropolitan Museum of Art, New York, in March 1991. I would like to express my thanks to Freda Murck and Munakata Kiyohiko, the organizers of the 


\section{Taoist mountains and grottoes}

The five sacred mountains, implanted at the four cardinal points and the center, "fixed" (zhen 鎮) the physical realm as the guardians of space. Their role in spiritual geography is analogous: as tutelary gods of the five directions, they marked, protected, and controlled sacred space. Consecrating, or sealing, a ritual area, whether an altar, a tomb, or an imperial capital, all involved the emplacement of five talismans or True Writs (zhenwen 真文) that oriented and secured sacred space in an analogous way.

The mountain, source of water and fertility, "gives birth to the myriad beings."4 Mountain and water, symbolizing tranquillity and movement, are of the essence in Chinese landscape painting. An out-flowing stream is a frequent iconographic feature in the depiction of grottoes, ${ }^{5}$ showing the mountain's interior as a source of life, of renewal, and as a place of passage - the stream providing the link of communication. In Tang poetry its flowing water was longingly scrutinized for messages from the beyond. ${ }^{6}$ Sometimes the stream is seen issuing from its hidden source in the mountain's cavernous interior, then flowing under an inviting bridge, while human figures approach the source of the water: suggestions, perhaps, that the world apart of the grotto is not unbridgeably separate from the world of human habitation and human concerns:

There is a sweet source to one side, its water warm and white. Visitors to the grotto brew their tea there. In front a rivulet flows sideways. Its rushing waters are swift and make a tumultuous noise flowing out of the grotto. A bridge twenty or thirty feet long and ten feet wide spans the rivulet. An imposing construction, it seems to be made of neither stone nor clay. Traversing the bridge... ${ }^{7}$

symposium, and to Nathan Sivin whose comments as discussant have been incorporated into the following. On the simultaneous exhibition, see the catalogue by Munakata Kiyohiko, Sacred Mountains in Chinese Art, Urbana and Chicago: Krannert Art Museum/University of Illinois Press, 1991.

${ }^{4}$ On this definition, from the second-century etymological dictionary Shuowen 説文, cf. Paul Demiéville, "La montagne dans l'art littéraire chinois," France-Asie 183 (1965): 7.

${ }^{5}$ See for example the stream gushing from the gaping mouth of the stalactite grotto in Wen Jia's 文劳 painting "Immortals' Mountain with Pavilions" (1555), a hanging scroll in the University Art Museum, Berkeley; reproduced in Munakata Kiyohiko, Sacred Mountains, p. 141.

${ }^{6}$ See Edward H. Schafer, Mirages on the Sea of Time: The Taoist Poetry of Ts'ao T'ang (Berkeley: University of California Press, 1985), pp. 42-43. Cf. the story of Li Ban 李班, set in the period of the Fu Qin 苻秦 (351-394), who discovered a grotto-dwelling of immortals by following a stream on which melon leaves floated to the world outside; see Shenxian ganyu zhuan 神仙感遇傳 (after 904) by Du Guangting 杜光庭, in Daozang 道藏 (hereafter D) fasc. 328 , no. 592 (in the concordance of titles by K. Schipper), 2.9b-10a.

${ }^{7}$ Luyi ji 錄異記 (completed 921-925), by Du Guangting (D 327, no. 591) 6.5a, describing the Wentang grotto 温湯洞. Cf. Fan Qi's 㚞圻 (1616-after 1694) "Peach Blossom Spring" in the Metropolitan Museum of Art, Munakata Kiyohiko, Sacred Mountains, p. 159. 
The same ambivalence is found in the theme that represents the mountain as a place of refuge from political and social turmoil and persecution, subject of the famous Peach Blossom Spring (taohua yuan 桃花源) tradition with its echoes and ramifications in Chinese literature and art. ${ }^{8}$ They typically involve some reference to the peach grove and grotto of Tao Yuanming's 陶淵明 (365-427) fable. Through these a fisherman, in search of the source of the river on which he is traveling, gains entrance to a separate world inhabited by refugees from a past age. ${ }^{9}$

But the mountain is also a place of refuge from civilization: a place of seclusion, liberation, and transcendence where the adept seeks medicinal herbs and minerals - including deposits of calcium carbonate left by the life-giving "milk" that was thought to drip from the stalactites in limestone caves. ${ }^{10}$ The sacred mountain was also the source of ores and other raw materials for alchemical preparations: here gold and mercury were found, the most highly refined endproducts of the slow evolution of metals and minerals, respectively, as well as jade, equally associated with alchemy and immortality." And the mountain held out the prospect of "encounters" (ganyu 感遇) with recluses and immortals. The exploration of its peaks and valleys, including the quest for grottoes as the dwellings of immortals, constitutes a major theme in Taoist hagiographic literature. ${ }^{12}$

In other words, the mountain is a place of initiation: a numinous but powerfully hostile place in which ordinary, sedentary humans, the men and women of the cultivated plains, could scarcely hope to survive. The Taoist, however, willingly leaves their civilization behind, ${ }^{13}$ taking possession of the demon-ridden highlands by means of his esoteric signs, magic mirrors, and ritual dance steps. The mountain, then, is a place of discipline and austerity. Far from the cereal-producing farmlands, the adept aspiring to transcendence relies on herbs, mushrooms, mineral elixirs,

${ }^{8}$ See Stephen R. Bokenkamp, "The Peach Flower Font and the Grotto Passage," Journal of the American Oriental Society 106 (1986): 65-77, and Richard M. Barnhart, Peach Blossom Spring: Gardens and Flowers in Chinese Paintings (New York: Metropolitan Museum of Art, 1983). A direct descendant of this theme from the late eighth century Guangyi ji 廣異記, preserved in Taiping guangji 太平廣記 (Peking: Zhonghua, 1961 edn.) 62.389-390, is discussed and translated in Glen Dudbridge, "Three Fables of Paradise Lost," Bulletin of the British Association for Chinese Studies 1988, pp. 30-32.

${ }^{9}$ See A.R. Davis, T'ao Yüan-ming (AD 365-427): His Works and Their Meaning (Hong Kong: Hong Kong University Press, 1983), pp. 195-201.

${ }^{10} \mathrm{Cf}$. Edward H. Schafer, Mao Shan in T'ang Times (Boulder: SSCR Monographs no. 1, rev. ed. 1989), pp. 22-24.

"Cf. "The Jade Field" (1549) by Lu Zhi 陸治 (Nelson-Atkins Museum of Art, detail in Munakata Kiyohiko, Sacred Mountains, pp. 142-43), accompanied by a poem in which Lu elaborates explicitly on these associations. On the ingestion of jade, see Max Kaltenmark, Le Lie-sien tchouan (rev. ed. Paris: Collège de France, 1987), pp. 36-37, n. 2.

${ }^{12}$ See the Shenxian ganyu zhuan, subject of a forthcoming study by the present author.

${ }^{13}$ On this theme in Taoist literature, cf. Demiéville, "La montagne," pp. 10-15. 
physiological meditations to recharge his vital humors, and the absorption of cosmic rays, until he finally discards nourishment altogether, living forever like the immortal bats inside the stone grottoes on no ordinary sustenance at all. The following cautionary example, inverting the theme of stone-eating immortals in antiquity, ${ }^{14}$ shows what lay in store for the unprepared intruder: like the "stone swallows" (shiyan 石燕) he became a permanent fixture of the grotto landscape. ${ }^{15}$ The surviving Buddhist monk in this tale is a practitioner of (Taoist) breathing techniques:

In the Qianfu reign (874-879), a monk from Tiantai 天台, proceeding east from Mount Tai 台山 (in Wuyi county 武義縣, Zhejiang) came upon a grotto within the bounds of Linhai county 臨海縣 (Zhejiang). Together with a likeminded monk he set out to explore it. For the first ten or twenty $l i$, the path was low, confined, and mostly waterlogged, but by degrees it leveled and broadened out. Gradually, mountains and rivers ${ }^{16}$ appeared. About ten $l i$ further, they discovered a market and inhabitants just as in the world [above]. The [Tiantai] monk was an adept at "swallowing the breath" (yanqi 燕氣) $)^{17}$ and felt neither hunger nor thirst. But the monk accompanying him suffered extreme hunger and went up to a food stall to beg for something to eat. A bystander said to them: "If you can bear your hunger and thirst and return quickly, you will come to no harm. But whoever swallows food from this place will meet with calamity when leaving it." His hunger was so severe that he persisted in obtaining food there. When he had finished eating it, they traveled together another ten or more $l i$. The road gradually narrowed to a défilé. Finally, they arrived at a small opening by which they made their exit. The monk who had eaten the food instantly turned into stone. After the monk from Tiantai left the mountain he eventually encountered someone and inquired which district it was. He proved to be already on the seacoast of Mouping 平平 (in northern Shandong)! ${ }^{18}$

The grotto, the invisible interior counterpart of the sacred mountain, has to be approached by special means. "When a superior master enters a mountain," wrote Ge Hong 葛洪 (283-343), “he carries the Esoteric Signs of the Three Sovereigns

${ }^{14}$ For example, Master Boshi 白石先生 who ate "boiled white stones." See Shenxian zhuan 神仙傳, attributed to Ge Hong 葛洪 (283-343), ap. Taiping guangji 7.44.

${ }^{15}$ On beliefs related to bats and swallows in grottoes, see Schafer, Mao Shan, pp. 24-25.

${ }^{16}$ Shanchuan 山川: the variant 山山 in Taiping guangji (see below), apparently a graphic error, led the modern editors of that version to mis-punctuate the phrase.

${ }^{17}$ See Henri Maspero, Taoism and Chinese Religion, translated by Frank A. Kierman (Amherst: University of Massachusetts Press, 1981), p. 468. The problem of sustenance in this environment is analogous to that of "embryonic respiration"; see ibid., pp. 459-505.

${ }^{18}$ Luyi ji 7.8b-9a; ap. Taiping guangji 398.3190-1. In the story cited in note 6 above, the melons eaten by the immortals inside the grotto likewise turn to stone on the threshold. 
and the Chart of the True Forms of the Five Sacred Mountains (wuyue zhenxing tu 五啍黄形圖) with him." 19 According to tradition, the earliest version of such a Chart was revealed to Emperor Wu of the Former Han in the year 110 B.C. ${ }^{20}$ The diagrams do not represent physical geography: ${ }^{21}$ they are talismans revealing the hidden structure of the Five Sacred Mountains. Along with graphic designs, they also provide the secret names by which an adept may know, and thus control, the mountain's deities and demons, as well as information about the sacred history and topography of the site.

In the Tang Dynasty, a now lost Chart of the True Forms of the Five Sacred Mountains was quoted as describing the cavernous interior of the mountain as well: "Beneath the grotto-heavens," the text reads, "a separate sun and moon dispense their light in turn to shine within." 22 The laconic remark reveals two striking features of these separate worlds: the grotto beneath and within the mountain is like the heavens above and beyond; and inside the confines of the mountain, heavenly bodies mark out the space and time of another universe. They do so according to their own scale and rhythm: night is turned into day, inside becomes outside, and generations elapse in the space of instants-experiences imaginatively elaborated in the narrative literature about journeys across the threshold between the world of humans and the grotto-heavens. To the Taoist imagination, such inversions and time-lapses were not isolated phenomena peculiar to these worlds. The altar (tan 壇) or ritual area (daochang 道場) and the alchemist's reaction-vessel (ding 鼎) were also cosmological models, or worlds apart, in which separate time cycles operated and natural processes could be

${ }^{19}$ Baopu zi neipian 抱朴子内篇, “Deng she 登涉," Wang Ming 王明 annot., Baopu zi neipian jiaoshi 抱朴子内篇校釋 (Peking: Zhonghua, 1980) 17. 274.

${ }^{20}$ Cf. Kristofer Schipper, L'empereur Wou des Han dans la légende taoïste (Paris: Ecole Française d'Extrême-Orient), pp. 1-2; Anna Seidel, "Imperial Treasures and Taoist Sacraments: Taoist Roots in the Apocrypha," in M. Strickmann, ed., Tantric and Taoist studies, vol. 2 (Brussels: Institut Belge des Hautes Etudes Chinoises, 1983), pp. 325-327 and 363.

${ }^{21}$ See the rubbing "Diagram of the True Forms of the Five Sacred Mountains" from a stone stele dated 1682 in Xi'an, Shaanxi (Field Museum of Natural History, Munakata Kiyohiko, Sacred Mountains, p. 113). For another rubbing from the same stele, together with two earlier versions showing the same five symbols, dated 1614 and 1378 , see Edouard Chavannes, Le T'ai Chan: essai de monographie d'un culte chinois (Paris: Ernest Leroux, 1910), pp. 415-424. Slightly different sets of symbols are transmitted in the Taoist canon, cf. Laszlo Legeza, Tao Magic: The Secret Language of Diagrams and Calligraphy (London: Thames and Hudson, 1975), pl. 6-10.

${ }^{22}$ See Franciscus Verellen, Du Guangting (850-933): Taoiste de cour à la fin de la Chine médiévale (Paris: Collège de France, 1989), pp. 131-132. This topos is regularly encountered in descriptions of grotto-heavens, beginning perhaps with the Jade Scripture of Tortoise Mountain quoted on p. 273 below. See also Zhen 'gao 畺誥 (499), compiled by Tao Hongjing

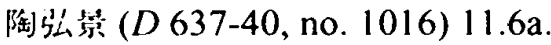


recreated according to accelerated rhythms. ${ }^{23}$

Just as the visible realm was demarcated by deified natural features, in particular mountains and rivers, so was the realm below measured out in grotto-heavens that were interconnected through a system of passageways and tunnels. Through these immortals roamed the subterranean heavens, like the ecstatic wanderers in Taoist meditation among the stars above. ${ }^{24}$ Characteristically, these channels of spiritual communion were not hermetically discontinuous with the physical environment that could be plumbed by human experience:

When Gao Pian 高駢 (d. 887) was commander of Shu 蜀 $(875-878),{ }^{25}$ he took a convict, bound him with a rope around the waist, and ordered him to probe the depth [of the grotto at Yuju guan 玉局觀 Temple] ${ }^{26}$ Only after two days did the rope come to a halt: [the convict] had emerged at the gate of the Grotto-heaven Temple (Dongtian guan 洞天觀) on Mt. Qingcheng 青城山. ${ }^{27}$

The word dong 洞, literally cavern or torrent, also has the meaning "to penetrate," both physically and intellectually; it is often used interchangeably with its nearhomophone tong 通 meaning to penetrate or communicate: the grotto is a place of transcendental passage, of revelation, and interconnected with other supernatural realms. In Taoist usage, dong is also a repository for sacred scripture, a meaning that is again relevant, as we shall see, to the concept of the grotto as a place of revelation. Finally, the word means empty, undifferentiated, and formless, pointing to its Taoist cosmogonic significance. The translation "crypt" would evoke its hidden nature and primitive association with burial and resurrection. However, the characteristic aspect of a dong is that of the "grotesque" stalactite cave represented in the detail from "Outing to Zhanggong Cave" below (after p. 289). The term dongtian 洞天, then, denotes a Taoist grotto conceived as heaven or paradise, and an abode of supernatural beings. As Michel Soymié remarked in his essay on Mount Luofu 羅浮山 (cf. no. VII in Appendix, a), the grotto-heaven is the quintessence of the mountain. If the ascent to the summit of the mountain is

${ }^{23}$ See, respectively, Kristofer Schipper and Wang Hsiu-huei, "Progressive and Regressive Time Cycles in Taoist ritual," in J.T. Fraser et al. eds., Time, Science, and Society in China and the West (Amherst: University of Massachusetts Press, 1986), pp. 185-205, and Nathan Sivin, "Chinese Alchemy and the Manipulation of Time," Isis 67 (1976): 513-526.

${ }^{24}$ See, e.g., Zhen' gao 11.7a and Isabelle Robinet, "Les randonnées extatiques des taoïstes dans les astres," Monumenta Serica 32 (1976): 159-273.

${ }^{25}$ On his appointment as military governor of Xichuan 西川 province in modern Sichuan, see Verellen, Du Guangting, pp. 53-55.

${ }^{26}$ The grotto beneath Yuju diocese in Chengdu, the capital of Tang Xichuan. See ibid., pp. $117-119$.

${ }^{27}$ Xu bowu zhi 縝博物志 (ca. 1050), by Li Shi 李石 (in Baihai 稗海) 3.2a. Mt. Qingcheng, no. $V$ in the list of grotto-heavens below, Appendix, $a$, is situated at a distance of sixty kilometers north-west of Chengdu. However, as the story about the monk from Tiantai demonstrates (p. 269 above), underground distances were magically foreshortened. 
regarded as a religious act, a spiritual journey requiring purification and esoteric knowledge, then the descent into the grotto-heaven represents that journey's culminating stage of initiation. ${ }^{28}$

\section{Grotto cosmography}

Taoist sacred geography reserves the most important place, beside the Five Peaks worshipped since classical antiquity, to the grotto-heavens. The late Tang court Taoist Du Guangting 杜光庭 (850-933) was an authority on the subject. ${ }^{29}$ His Record of Grotto-heavens, Blessed Places, Ducts, Peaks, and Great Mountains (Dongtian fudi yuedu mingshan $j i$ 洞天福地訔煩名山記) ${ }^{30}$ stands as the most comprehensive exponent of this Taoist world-view at the end of a long medieval tradition. The author's preface, signed “Feathered Man of Huading 華頂, at Yuju in Chengdu, ${ }^{31}$ on 19 September 901 ," places the grotto-heavens in the following cosmological context:

When Heaven and Earth divided and the clear [ethers ( $q i$ 氣)] separated from the turbid, ${ }^{32}$ they fashioned the great rivers by melting and the lofty mountains by congealing. Above they laid out the stellar mansions, below they stored the grotto-heavens. The affairs of each of these being administered by great sages and superior Perfected, they contain divine palaces and spirit residences, jade halls and gold terraces: soaring structures of congealed clouds, formed from solidified ether.

The emerald pool of Jade Pond (Yaochi 瑶池) flows out to the four corners; the precious grove of pearl trees (zhushu 珠樹) [on Mount Kunlun 崖 崙] $]^{33}$ spreads luxuriously upward: breeding grounds for the divine phoenix

${ }^{28}$ See Michel Soymié, "Le Lo-feou chan: étude de géographie religieuse," Bulletin de l'Ecole Française d'Extrême-Orient 48 (1954): 92. In gnostic terms, the "secret" and "hidden" aspect of the dong emphasized by Soymié accords with the dictionary meanings "deep understanding" and "clear discernment."

${ }^{29}$ Cf. Edward H. Schafer, Pacing the Void: T'ang Approaches to the Stars (Berkeley: University of California Press, 1977), p. 250.

${ }^{30}$ D 331 , no. 599.

${ }^{31}$ The epithet Huading yuren 華頂羽人 refers to Du's early career at Mt. Tiantai in Zhejiang; see Verellen, Du Guangting, p. 13; on his residence at the Yuju diocese in Sichuan, ibid., pp. 116-119.

${ }^{32}$ Cf. Huainan zi 淮南子, “Tianwen xun” (Liu Wendian 劉文典 et al. eds., Huainan honglie jijie 淮南鸿烈集解, Peking: Zhonghua, 1989, pp. 79-80). Cf. John S. Major, Heaven and Earth in Early Han Thought: Chapters Three, Four, and Five of the Huainanzi (Albany: State University of New York Press: 1993), p. 62.

${ }^{33}$ The Jade pond and pearl trees were features of the topography of Mount Kunlun, the axis mundi and summit of the world. From the four corners of Kunlun issued four mythical rivers. Cf. Major, Heaven and Earth, pp. 150-158. 
and the flying qiu-dragon (feiqiu 飛虬), habitat of the heavenly unicorn and [auspicious] marsh horse (zema 澤馬).

The sun steers its course while the stars orbit in their stations. Harboring the wind and the rain, holding clouds and thunder in store-pivot of Heaven and Earth, axle of Yin and Yang! Abruptly [Mt. Kunlun] soars above the sea and recedes into the heavens. Surrounded by non-buoyant water (ruoshui 水) ${ }^{34}$ and barred by giant waves (hongtao 洪罍), sunshine sheds no light and human steps do not reach there.

True scriptures and esoteric volumes relate and transmit these things. The Grand Astrologer (taishi gong 太史公) ${ }^{35}$ said: “In the outlying regions (dahuang 大荒) there are five thousand great mountains (mingshan 名山). Among these, five peaks (wuyue 五获) function as regulators (zhen 鎮) and ten mountains act as [their] assistants (zuo 佐)." The Jade Scripture of

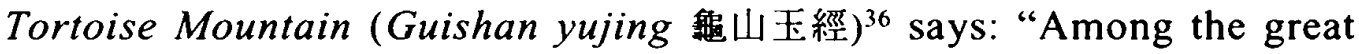
heavens there are thirty-six grotto-heavens (dongtian 洞天). They separately contain suns, moons, and stars, as well as the palaces of the divine immortals who control blessings and chastisements and keep the registers of life and death. That is where the exalted Perfected reside and immortal princes dispose." In addition, there are the five peaks beyond the seas, the three isles and ten continents, the thirty-six pure hermitages (jinglu 靖鹰), the seventytwo blessed places (fudi 福地), the twenty-four dioceses (zhi 治), the four regulators and sundry mountains. ${ }^{37}$

Du Guangting's geography sets out two separate series of grotto-heavens, entitled "Ten Great Grotto-heavens" and "Thirty-six Grotto-heavens." They are listed in the Appendix, together with the modern equivalents of their localizations.

\footnotetext{
${ }^{34}$ Ruoshui: also the name of one of the four rivers mentioned above (cf. Major, Heaven and Earth, ibid.).

${ }^{35}$ I.e., Sima Qian 司馬遷 (ca. 145-ca. 86 B.C.) or his father, authors of the Shiji 史記. Nothing resembling the remark quoted below seems to have come down in that work. It is possible that $\mathrm{Du}$ is citing conventional wisdom: a similar reference occurs, in a similar context, in the inscription Tianzhu guan ji 天柱觀記 by the Taoist poet Wu Yun 吳筀 (d. 778). See Yuhai 玉海 (Taipei: Huawen shuju, 1964 facsimile of 1337 edition) 20.29b; cf. Soymié, "Le Lo-feou chan," p. 90.

${ }^{36}$ Guishan yujing: also referred to as Guishan boyu shangjing Baichuan xuehai edition of Mingshan dongtian fudi ji la, and again in Du Guangting's preface to Tiantan Wangwu shan shengji ji 天壇王屋山聖跡記 (D 610, no. 969) 1a. Tortoise Mountain is another name for the residence of $\mathrm{Xi}$ wang mu. The scripture appears to be lost.

${ }^{37}$ On these categories, see Verellen, Du Guangting, pp. 136-137, and Thomas Hahn, "The Standard Taoist Mountain," Cahiers d'Extrême-Asie 4 (1988): 145-156.
} 


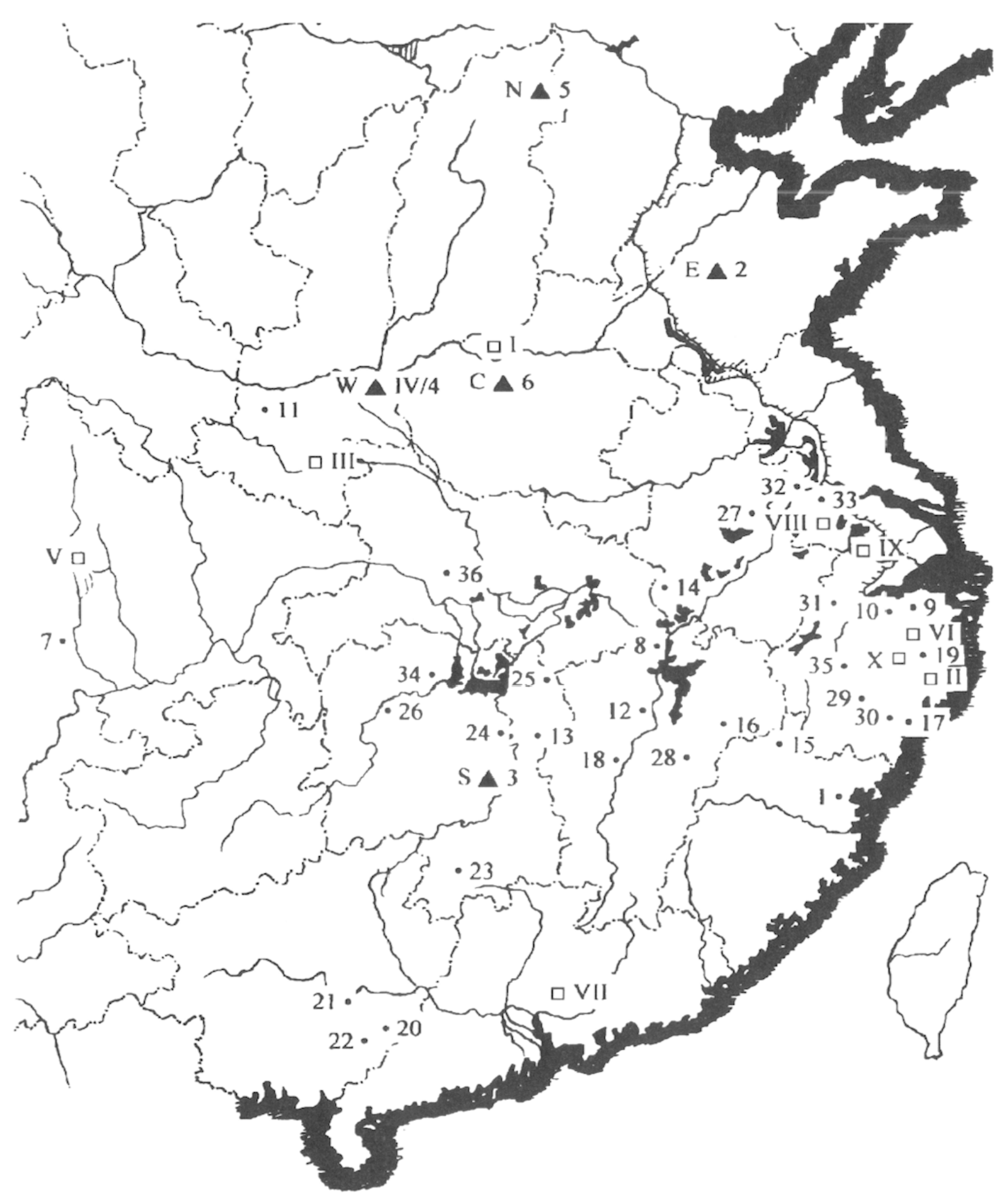

Distribution of the Ten Major $\square$ and Thirty-six Lesser - Grotto-heavens Including the Five Sacred Peaks A: [C] Central Peak 中獄 (6); [E] Eastern Peak 東獄 (2) [N] Northern Peak 北嶽 (5); [S] Southern Peak 南訔 $(3)$; [W] Western Peak 西獄 $(I V, 4)$ 
Attempts to discover the relationship between the two series and their respective origins remain inconclusive, but a general outline of the historical development of the idea can be given. As Miura Kunio demonstrates convincingly, a series of thirtysix grottoes antedated that of ten. ${ }^{38}$ In particular, Miura cites several early sources referring to grotto-heavens, including the Life of Lord Mao (Maojun zhuan 茅君傳), a text issued from the Shangqing 上淸 revelations at Maoshan during the years 364370 , which suggest that those grottoes that formed the eventual series of ten were originally part of a different set comprising thirty-six. ${ }^{39}$ The same conclusion had been reached by Michel Soymié three decades earlier, ${ }^{40}$ overturning the hypothesis to the contrary by Edouard Chavannes. ${ }^{4 l}$ While Chavannes' theory that the series of thirty-six grotto-heavens were only instituted under the Tang does not stand up to the evidence since identified, it is fair to say that the cosmology of the Taoist grottoheavens was only fully systematized by the Tang authors Sima Chengzhen 司馬承禎 (647-735) and Du Guangting. ${ }^{42}$ The Plan of Celestial and Terrestrial Palaces and Residences (Tiandi gongfu $t u$ 天地宮府圖), compiled by the former probably in the early eighth century, ${ }^{43}$ is the first to set out side by side the two complete series that are found in Du Guangting's early tenth century comprehensive treatise and were further elaborated by Li Sicong 李思聰 in the eleventh. ${ }^{44}$

The earliest textual evidence, then, points to a significant development, if not the origin, of the notion of grotto-heavens in the context of the Maoshan revelations. I am referring to the Muojun zhuan just mentioned, considered by Isabelle Robinet the earliest extant text to treat the subject of dongtian, ${ }^{45}$ the Ziyang zhenren

\footnotetext{
${ }^{38}$ Miura Kunio 三浦國雄, “Dōten fukuchi shōkō 洞天福地小考," Tōhō shūkyō 東方宗教 51 (1983): 4-5.

${ }^{39}$ Maojun zhuan ap. Taiping yulan 太平御覧 (Peking: Zhonghua, 1960 ed.) 678.4b-5a. The passage states that there were 36 grotto-heavens within the earth, and then proceeds to list I-X below, followed by an assortment of other great mountains. Similarly, the Rhapsody on Mt. Luofu of Xie Lingyun 謝靈運 (358-433) names Zhuming yaozhen (Appendix, a, VII) as no. 7 in a series of 36 (“Luofu shan fu 羅浮山賦” ap. Yiwen leiju 蓕文類聚, Shanghai: Zhonghua, 1965 ed., 7.140; on Xie's mountain poetry, cf. Demiéville, "La montagne dans l'art littéraire," pp. 18 ff.); again, Zhen'gao 11.5b-6a, names VIII (Appendix, a) as no. 8 in a set of 36 .

${ }^{40}$ Soymié, "Le Lo-feou chan," pp. 89-90.

${ }^{41}$ Edouard Chavannes, "Le jet des dragons" [posth.], Mémoires concernant l'Asie Orientale 3 (1919) : 131-133.

${ }^{42}$ Cf. Miura Kunio, "Dōten fukuchi shōkō," pp. 1-3. Chavannes' point that the place names in Du Guangting's list of thirty-six reflect Tang nomenclature (p. 132) in fact demonstrates that Du's and Sima's localizations of the ancient holy places conformed with contemporary usage.

4.3 Tiandi gongfu tu ap. Yunji qiqian 雲笈七襶, D 677-702, no. 1032, j. 27.

${ }^{44}$ See Dongyuan ji 洞淵記 (1050), D 732, no. 1063, j. 2.

${ }^{45}$ Isabelle Robinet, La révélation du Shangqing dans l'histoire du taoïsme (Paris: Ecole Française d'Extrême-Orient, 1984), vol. 2, p. 397.
} 
neizhuan 紫陽眞人内傳, dated $399,{ }^{46}$ and the first extended discussions of grottoheavens found among the Declarations of the Perfected (Zhen'gao 眞誥). This collection of information about the pantheon and the organization of the invisible universe, completed by Tao Hongjing 陶弘景 in 499, contains fragments of the Shangqing revelations in the 360 s together with Tao's commentaries. ${ }^{47}$ Although Du Guangting's preface to the Dongtian fudi yuedu mingshan ji suggests that the heavenly and subterranean spheres were creatcd as counterparts, it is not clear whether the system of thirty-six grotto-heavens was also conceived as mirroring the thirty-six heavens of Shangqing cosmology. ${ }^{48}$ The assumption that the representation of the great mountain caverns as grotto-heavens took shape in connection with the Maoshan revelations nevertheless opens a plausible interpretive perspective.

The grotto-heavens clearly constituted a form of interiorized "counter-universe," to be contemplated by the methods of visualization. Meditation and visualization techniques were at the heart of the scriptural movement and mystical practices of Maoshan. The parallel notion of a correlated microcosm inside the body developed within the same context. ${ }^{49}$ In short, the visualization of the grotto-heavens forms part of the same general movement towards interiorization that characterized Shangqing meditation from the outset and in time produced such mental disciplines

${ }^{46} D 152$, no. 303. This hagiography of the Maoshan saint Zhou Yishan 周) (ll) (fl. first century B.C.) refers by name to the cavern heavens $I$ and $6(5 b, 7 b-8 a)$ in the Appendix below. The passage is discussed in Miura Kunio, "Dōten fukuchi shōkō," pp. 3-4.

47 Zhen'gao (see n. 22 above), especially juan 11; cf. Robinet, La révélation $d u$ Shangqing, vol. 2, pp. 325-27 and Michel Strickmann, Le taoisme du Mao Chan : chronique d'une révélation (Paris: Collège de France, 1981), pp. 1-2. Strickmann (ibid., p. 39) confirms, though without giving his reasons, that Du's religious geography derived from the Maoshan revelations. Of course, this is not to deny that constituent elements of grotto lore existed earlier and that even conceptions of the underworlds inherited from antiquity exerted an influence. See also below.

48 Based on a four-fold subdivision of the fundamental nine-layered structure. See Robinet, La révélation du Shangqing, vol. 1, p. 131. The Shangqing waiguo fangpin qingtong neiwen 上清外國放品青童内文 (fifth or sixth century), D 1041, no. 1373, B.2a-5a and passim, names side by side thirty-six heavens and thirty-six terrestrial regions, suggesting such a correspondence. The Scripture of the Marvelous Beginning, Taishang miaoshi jing 太上妙始 經 ( $D 344$, no. 658), a Heavenly Master (Tianshi 天師) treatise on mythical geography dating probably also from the fifth century, presents a scheme of thirty-six mountains beside the Five Peaks and Four Ducts (2a, 3b), without reference to either grottoes or heavens. Possibly, the idea of grotto-heavens stood at first in competition with the second-century Heavenly Master system of twenty-four dioceses (ershisi zhi 二十四治) which corresponded with the lunar mansions (cf. Verellen, Du Guangting, p. 117). In the work of the Tang codifiers, however, the two systems, along with further categories of religious geography, appear fully integrated. See Dongtian fudi yuedu mingshan ji $11 \mathrm{~b}-15 \mathrm{a}$ and passim.

${ }^{49}$ On the correlation between the three grottoes of the universe, the mountain, and the body, see Miura Kunio, "Dōten fukuchi shōkō," pp. 11-18. 
as "inner alchemy" (neidan 内丹), in which the body became a spiritual reactionvessel, and “inner contemplation" (neiguan 内觀), a regime of systematic introspection of the practitioner's own body and mind. ${ }^{50}$ At the same time, the interest in grotto-heavens corresponded to a development in Shangqing hagiography that found expression in such works as the sixth-century Lives of the Grottoimmortals (Dongxian zhuan 洞仙傳). ${ }^{51}$ Drawing on the Zhen'gao and another compilation by Tao Hongjing, the Ranks and Offices of the Perfected and Supernatural Beings (Dongxuan lingbao zhenling weiye $t u$ 洞玄露蜜黄露位業圖), ${ }^{52}$ the Lives of the Grotto-immortals reflects both Shangqing methods of immortality and hierarchical theories postulating different classes of immortals, including earthimmortals (dixian 地仙) who dwelled in "grotto-residences" (dongfu 洞府)..$^{53}$

Where does this leave the series of ten grotto-heavens? Michel Soymie, regarding that series as a later development, argued that the number ten carried no numerological or cosmological significance in pre-Buddhist China, while the number thirty-six, on the other hand, belonged with seventy-two and 360 among the important multiples of the symbolic number nine prevalent in indigenous Chinese spatial and calendrical concepts. ${ }^{54} \mathrm{~A}$ Buddhist influence seems indeed likely, but two qualifications may be made: the Ten Celestial Stems (shigan +干) figured prominently among Chinese spatial and calendrical concepts since Shang times; and, as regards the relative date of the two series, the adoption of the Ten Directions (shifang $+f_{j}$ ) of Buddhist cosmology into Taoist liturgical space was among the earliest and most widespread of borrowings, well-documented in Lingbao 霝寶 scriptures since the fourth century. ${ }^{55}$ The earliest available textual evidence for a separate series of ten grotto-heavens, meanwhile, dates to the fifth and sixth

${ }^{50}$ See Robinet, La révélation du Shangqing, vol. 1, p. 176. On the terms neidan and neiguan, see Farzeen Baldrian-Hussein, "Inner Alchemy: Notes on the Origin and Use of the Term neidan," Cahiers d'Extrême-Asie 5 (1989-1990): 163-90, and Livia Kohn, "Taoist Insight Meditation: The Tang Practice of neiguan," in L. Kohn and Yoshinobu Sakade, eds., Taoist Meditation and Longevity Techniques (Ann Arbor: Center for Chinese Studies, 1989), pp. 193-224.

${ }^{51}$ Lost as an integral collection, this work is known today mainly from citations in Song anthologies. See the refacimento in Yan Yiping 嚴一萍, Daojiao yanjiu ziliao 道教研究資料 (Taipei: Yiwen,1974), vol. 1, and the study “Dongxian zhuan yanjiu 洞仙傅研究” by Li Fengmao 李豐森 in his Liuchao, Sui, Tang xiandao lei xiaoshuo yanjiu 六朝隋唐仙道類小説研 完 (Taipei: Xuesheng shuju, 1986), pp. 187-224.

${ }^{52}$ See the ninth-century edition by Lüqiu Fangyuan 䦎丘方遠, $D 73$, no. 167.

${ }^{53}$ See Li Fengmao, "Dongxian zhuan yanjiu," pp. 189-194 and 208-215.

${ }^{54}$ Soymié, "Le Lo-feou chan." p. 89.

${ }^{55}$ Erik Zürcher, "Buddhist Influence on Early Taoism: A Survey of Scriptural Evidence," T'oung Pao 66 (1980): 124-129. Robinet, La révélation du Shangqing, vol. 1, p. 97, affirms that the notion of the ten directions of space was still absent from Shangqing meditation practice. Conceivably, the introduction of a series of ten "superior" grotto-heavens represented a new dispensation put forward by the Lingbao movement, but I am not aware of any clear evidence for this. 
centuries. The Daoji jing 道迹經, a lost work of approximately Tao Hongjing's (456-536) period, ${ }^{56}$ affirmed that the Five Sacred Peaks as well as the Great Mountains - of undetermined number - all had grottoes. The text then proceeds to list a series of ten mountains which, except for a slight irregularity in the sequence, corresponds in every detail to Du Guangting's series of ten. The names of the ten mountains' respective grotto-heavens are listed separately and in their usual order. ${ }^{57}$ The Shangqing manual Qiyu xiuzhen zhengpin tu 七域修滇證品圖 is perhaps the first to explicitly refer to the two series of ten and of thirty-six grotto-heavens side by side..$^{58}$

It may be noted that the authors of the landmarks of Taoist sacred geography, Tao Hongjing, the compilers of the Wushang biyao encyclopedia, Sima Chengzhen, and Du Guangting, were all closely involved in court affairs and provided politicoreligious services to their respective rulers. The Wushang biyao, conceived as a summa of Taoist knowledge, was intended as a spiritual prelude to the unification of the empire. ${ }^{59}$ Similarly, Du Guangting's comprehensive systematization of traditions relating to local cults served as a unifying factor in imperial politics at the end of the Tang and early Five Dynasties period. ${ }^{60}$ Like the universal gazetteers compiled from local administrative reports, ${ }^{61}$ comprehensive and authoritative inventories of the realm's religious geography were of both symbolic and practical value to sovereigns. Tang imperial ritual required reliable guides to the cosmology of sacred sites, especially grotto-heavens, and to their localizations in this world. The possession of a representation of the spiritual realm, moreover, could stand symbolically, like the circumambulation of the Mingtang 明堂 temple, ${ }^{62}$ for possession of the far-flung sites themselves. As emperor Xuanzong 玄宗 explained

${ }^{56} \mathrm{Cf}$. Robinet, La révélation du Shangqing, vol. 1, pp. 110-111.

${ }^{57}$ Daoji jing, cited in the Taoist encyclopedia Essentials of Supreme Secrets, Wushang biyao 無上祕要 (ca. 574), D 768-79, no. 1138, 4.13b-14b. The irregularity is due to three inversions (numbers V-IV, VII-VI, IX-VIII), suggesting a scribal error, perhaps in the transcription of a list originally set out in two registers. The Guishan boyu shangjing (cf. $\mathrm{n}$. 36 above) also referred to ten grotto-heavens (see Tiantan Wangwu Shanji, Preface, 1a).

${ }^{58}$ Qiyu xiuzhen zhengpin $t u(D 196$, no. 433) $5 \mathrm{~b}$. This work is of an uncertain date later than the fifth century.

${ }^{59}$ See John Lagerwey, Wu-shang pi-yao: somme taoiste du VIe siècle (Paris: Ecole Française d'Extrême-Orient, 1981), pp. 4-21.

${ }^{60}$ See F. Verellen, "Liturgy and Sovereignty: The Role of Taoist Ritual in the Foundation of the Shu Kingdom (906-925)," Asia Major, 3rd ser., 2.1 (1989): 73-78 and idem, "A forgotten T'ang Restoration: The Taoist Dispensation after Huang Ch'ao," forthcoming in Asia Major, 3rd ser., 7.1 (1995).

${ }^{61}$ See the catalogue of such works in Zhang Guogan 嬩國梌, Zhongguo gu fangzhi kao 中 國古方志考 (Shanghai: Zhonghua, 1962), pp. 47-125.

${ }^{62}$ On the ritual symbolism of this institution, see Henri Maspero, "Le Ming-t'ang et la crise religieuse chinoise avant les Han," Mélanges chinois et bouddhiques 9 (1948-1951), pp. 1-71. The temple's nine chambers represented, among other things, the nine provinces of China; ibid., 17, 33. 
in 738 , in a prayer inscribed on a copper plaque to be cast into a grotto at Mt. Heng (cf. Appendix, b, no. 3), this local imperial rite was also carried out by proxy:

In accordance with the divine scriptures of Shangqing, I cast this imperial writ into the grotto of the immortals of Zigai 紫蓋. ${ }^{6.3}$ The dignity of the sovereign would be diminished if he went forth in person; thus prevented from offering homage myself, l respectfully command the Taoist master (daoshi 道士) Sun Zhiliang 孫智涼 to convey this missive (xinjian 信簡) so that it be brought to your attention. Let golden dragons transmit it by relay! ${ }^{64}$

\section{Grottoes in Tang Ritual}

The Tang imperial court took more than a passing interest in grotto-heavens. The ritual in which Xuanzong participated in the passage cited above was known as Casting Supplications Conveyed by Dragon-effigies into the Mountains-i.e. into communicating grottoes-and Rivers (tou shanshui longjian 投川水龍簡). A rite of legitimation, intrinsically related to the ancient feng 封 and shan 禪 sacrifices performed sporadically by emperors at Mount Tai, ${ }^{65}$ it was thought to procure blessings for the emperor and the dynasty. Its frequent practice under the Tang has been richly documented by Edouard Chavannes.

Among the numerous stele inscriptions with a bearing on the ritual of Casting Dragons cited by Chavannes is the famous "Inscription on the Altar of the Immortal Magu" by the calligrapher and scholar Yan Zhenqing 顔眞卿 (709-784), who had served as prefect of the area surrounding Mt. Magu in Jiangxi (Appendix, b, no. 28). After recounting the hagiography of the goddess, Yan records that:

In the third year of Dali (768), Zhenqing was named prefect of Fuzhou 撫州. According to the local administrative report (tujing 圆經), Mt. Magu is situated in Nancheng county. On its summit is an ancient altar, and tradition relates that it was here that Magu obtained the Way... In the fifth year of Tianbao (746), [the emperor Xuanzong] had a dragon cast into the stone pond of the cataract. A yellow dragon appeared. Moved by gratitude, Xuanzong ordered the restoration of the dwelling of the immortal. ${ }^{66}$

${ }^{63}$ One of the peaks of Hengshan, not to be confused with Appendix, b, no. 36 .

64 “Nanyue toulong gaowen 南徬投龍告文," in Wang Jun 汪落, comp., Shicr yan zhai

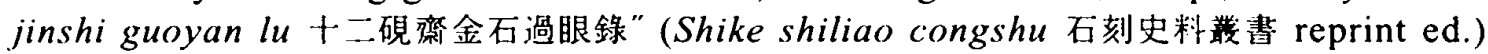
$11.18 \mathrm{~b}-19 \mathrm{a}$. See the full translation and discussion of the inscription in Chavannes, "Le jet des dragons," pp. 55-58.

${ }^{65}$ See Howard J. Wechsler, Offerings of Jade and Silk: Ritual and Symbol in the Legitimation of the T'ang Dynasty (New Haven: Yale University Press, 1985), pp. 176-189.

66 “Magu xian tan ji 麻姑仙壇記,” in Wang Chang 王衵, ed., Jinshi cuibian 金石萃編 (Xi'an: Shaanxi renmin yishu, 1990 ed.) $96.1 \mathrm{a}-\mathrm{b}$; Chavannes, "Le jet des dragons," pp. 103-108. 
The writings of Taoist liturgical specialists under the Tang inform us that the mountain grotto represented the ideal space for the performance of Taoist rites, whether for the court or for the benefit of local communities. The following

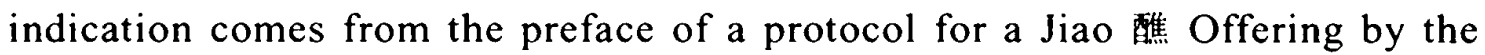
eminent liturgist Zhang Wanfu 張萬福, a contemporary of Sima Chengzhen at the court of Xuanzong in the early eighth century. The preface discusses the general purpose and efficacy of the ritual, as well as matters of procedure:

The Offering is the means by which we present our sincerity to Heaven and Earth and pray for blessings to the unseen gods. Unless we are fully devoted we will fall short of entering into communication and establishing contact; but where there is complete sincerity, blessings are unfailingly obtained in response... The most excellent way to establish the altar (tan 壇) is to avail oneself of a grotto (dongxue 洞穴) among the Great Mountains. Failing that, a secluded and solitary place will be acceptable... If [the site is] a mountain grotto, and you have no mats, cover the grass with dry leaves. ${ }^{67}$

One of the most numinous of grotto-heavens, the Golden Altar Jintan 金增 situated beneath Maoshan (Appendix, a, no. VIII), was believed to be the scene of rituals and scripture recitations performed by immortals. ${ }^{68}$ No doubt it was this notion of the grotto as the ideal sanctuary that filled visitors with a sense of reverence that has been compared to the awe experienced by a Christian pilgrim on entering a Gothic cathedral. ${ }^{69}$

Further in the text, Zhang Wanfu's manual explains the detailed procedure for establishing the sacred area according to the Lingbao liturgical tradition: a space of prescribed dimensions is cordoned off with ropes; into this perimeter are set five oriented gates; emplacements are installed for the deities about to receive offerings; a rite of purification completes the consecration of the ground. ${ }^{70}$ The ideal celebration thus took place - if not within a grotto - in a natural setting. This is how Kristofer Schipper has described the conceptual construction of the ritual area in which Taoist Offerings are performed today:

The Taoist altar is itself a mountain. An enclosed space, secret and covered (thus "inner"), it is called daochang, "place or enclosure of the Tao." Nonetheless, to enter this place of retreat in order to perform the rites is called, in

${ }^{67}$ Jiao sandong zhenwen wufa zhengyi mengwei lu licheng yi 醮三洞黄文 $\mathrm{IL}$ 法证: 一盟威籍 立成儀 $(D 878$, no. 1212) la.

${ }^{68}$ See Edward H. Schafer, "Empyreal Powers and Chthonian Edens: Two Notes on T'ang Taoist Literature," Journal of the American Oriental Society 106 (1986): 669 and idem, Mao Shan, pp. 67-68.

${ }^{69}$ Schafer, Mao Shan, p. 23.

${ }^{70}$ Jiao sandong zhenwen wufa zhengyi mengwei lu licheng yi 2a-6a. 
the language of the daoshi: "to go into the mountain." ... Standing in the center, before the Golden Gate, the officiating priest can be said to be standing at the foot of a sacred mountain, the dwelling of the gods. But the decoration is not restricted to the wall facing the priests; it surrounds them on all sides.... This multi-level mountain - the altar-is located around the officiating priest rather than the priest being on the altar: he is in the mountain, the Space of the Tao. ${ }^{71}$

The idea of the grotto as sanctuary was as central to private practice as to public liturgy: this is how the Book of Salvation (Duren jing 度人經), the fundamental Lingbao scripture from the late fourth century that occupies an important place in Taoist ritual practice to this day, describes the mental construction of a ritual cosmos inside a private oratory:

Close your eyes and silently meditate upon your body. Amidst green, yellow, and white tricolor vapors, within and without become densely somber. The green dragon, white tiger, red bird, dark tortoise [the emblematic animals of the four directions of space], as well as lions and white cranes, form around you. Sun and moon shed their light and illumine the grotto inside the resplendent oratory... ${ }^{72}$

The same concept of an interiorized ritual space is found in modern Taoist practice. To quote K. Schipper again, the following passage describes the hidden, secret ritual that takes place within the body of the priest in parallel with the performance of the visible, exterior rites:

This closed space is a world apart, but it is called altar, sacrificial mound, mountain. This mountain, however, has an inner face and an outer one. The surface of the mountain has been detached, so to speak, and now encircles the "place of the Tao." The mountain has become concave instead of convex.

In the middle of the ritual area then, we find ourselves inside a mountain; but since we perceive its surface, we must also be standing outside it: we are both "inside" and "outside." We also see the sphere of the altar as something continuing outward from the master's own body. ${ }^{73}$

For the priest, the adept, the individual meditating in a pure chamber or oratory, the human body is a grotto, visualized as a mountain landscape inhabited by gods. His viscera become orbs that illuminate this inner sanctuary. The grotto as an idealization of sacred space can be considered as the object and the product of a

${ }^{11}$ Kristofer Schipper, The Taoist Body, translated by Karen C. Duval (Berkeley: University of California Press, 1993), pp. 91-93.

${ }^{72}$ Lingbao wuliang duren shangpin miaojing 露窗無量度人上品妙粨 1 ( $D$ 1, no. 1) 1.5a (commentary).

${ }^{73}$ Schipper, The Taoist Body, p. 99. 
meditative projection, the discipline that enables the adept to make the hidden world manifest and recreate ideal and remote spaces around and within himself.

On another level, this can more generally be described as an object of landscape representation in Chinese religious aesthetics. ${ }^{74}$ The creation of a microcosm within the confines of an artificial landscape or even a container featuring rocks and dwarfed trees has been exhaustively analyzed by Rolf Stein. ${ }^{75}$ The connection with meditation and visualization is made explicit in the early eighteenth century painting by Yuan Jiang 袁江 entitled “The Gazing Garden,"76 believed to show a private Manchu garden in Nanjing, complete with representations of mountains and grottoes. The viewer allows his gaze to wander through and explore these iconic landscapes, not unlike the popular visualization images depicting the Western Paradise. Jade miniature mountains served a similar purpose. ${ }^{77}$ The religious, or proto-religious, interest of these objects lies in what Rolf Stein called the "magic of depiction" and the "magic of smallness."

The magic of depiction and of smallness could not be better illustrated than by Stein's quotation of the early ninth century tale about the Taoist Yiqi Xuanjie 伊祁玄 解. Xuanjie is retained at the imperial court against his wishes. At length, he creates a miniature landscape for the emperor's diversion, which includes a wooden sculpture of the Isles of the Immortals. When the emperor expresses his regret at being unable to visit this inaccessible paradise, the Taoist makes himself smaller and smaller until he finally disappears into that world of his own creation. ${ }^{78}$ The making of a separate space that may be inhabited by the adept is the theme of the myth of the World Within a Gourd. ${ }^{79}$ This construction is directly analogous to that of the grotto and involves the imagination of paradisiac "gourd-heavens," a subject also treated by R. Stein. ${ }^{80}$

\footnotetext{
${ }^{74}$ See Hubert Delahaye, Les premières peintures de paysage en Chine: Aspects religieux (Paris: Ecole Française d'Extrême-Orient, 1981), especially pp. 48-51.

${ }^{75}$ Rolf A. Stein, The World in Miniature: Container Gardens and Dwellings in Far Eastern Religious Thought. Translated by Phyllis Brooks (Stanford: Stanford University Press, 1990).

76 "Zhanyuan 瞻凮," handscroll in the Metropolitan Museum of Art. See Barnhart, Peach Blossom Spring, pp. 116-17.

${ }^{77}$ See for example the eighteenth-century nephrite carvings in the Cleveland Museum of Art reproduced in Stephen Little, Realm of the Immortals: Daoism in the Arts of China (Cleveland: Cleveland Museum of Art, 1987), p. 48.

${ }^{78}$ Duyang zabian 杜陽雜編, by Su E 穌鹗, Gujin shuobu congshu 古今説部丵書 ed. (Shanghai: Shanghai wenyi, 1991) B.2b-3b; Stein, The World in Miniature, pp. 52-53.

${ }^{79}$ See especially the legend of Lord Gourd (Hu gong 壶公) in Shenxian zhuan 神仙傳 (ca. 320 ) ap. Taiping guangii $12.80-82$.

${ }^{80}$ The World in Miniature, pp. 58-77.
} 


\section{Mythological Themes}

Three major mythological themes running through the conception of the grottoheavens may be distinguished, though ultimately they are closely related: (1) the grotto as womb, (2) the grotto as tomb, and (3) the grotto as paradise. Let us briefly consider these in turn.

Two well-documented cases for the grotto as womb in a Buddhist context have been described in recent years: the first by François Bizot, with reference to a popular Khmer cult centered on the Birth Cave of Phnom Sampau near Battambang ${ }^{81}$ the second by Rolf Stein, based on reincarnation rituals performed at the Cave of a Thousand Buddhas (Qianfo dong 千佛洞) at Wutai shan 严辜山 in Shanxi, and again several sites outside China (in Tibet, Nepal, India, Indochina and Japan). ${ }^{82}$ The ceremony involves rites of purification and penitence in addition to a strenuous passage through the grotto, in other words, a rite of spiritual rebirth through the renunciation of sin.

The Buddhist Birth Cave of Wutai shan is an isolated case in China ${ }^{83}$ and though it shows signs of Taoist influence, it has no close Taoist counterpart. If abstraction is made from the literal imagery of the rebirth cults described by Bizot and Stein, however, such caves share with Taoist grottoes the idea that they are places of transcendental passage. The notion of the grotto as matrix is moreover consistent with the etymology of dong that equates the term with hundun 混沌, "chaos," the "undifferentiated" beginning, an interpretation that is akin to the myth representing the grotto as a place of cosmic revelation.

The mythical hero Yu 禹 received from the god Fu Xi 伏羲 in the depths of a primordial cave the Chart of the Eight Trigrams and the ruler with which to fashion Heaven and Earth and measure out Time. As Max Kaltenmark has demonstrated, the hero's revelatory quest is typically associated with initiatory trials and labyrinthine wanderings in the bowels of the earth. ${ }^{84}$ Similarly, when Yu was laboring to subdue the flood waters, a divine being revealed to him the Five Talismans of the Numinous Treasure (Lingbao wufu 霝寶五符) that enabled him to control the deluge. His task completed, Yu deposited the Five Talismans, later

${ }^{81}$ F. Bizot, "La Grotte de la naissance: Recherches sur le bouddhisme khmer (II)," Bulletin de l'Ecole Française d'Extrême-Orient 67 (1980): 221-273.

${ }^{82}$ R.A. Stein, Grottes-Matrices et lieux saints de la déesse en Asie orientale (Paris: Ecole Française d'Extrême-Orient, 1988).

${ }^{83}$ See Raoul Birnbaum, "Secret Halls of the Mountain Lords: the caves of Wu-t'ai shan," Cahiers d'Extrême-Asie 5 (1991): 137-140. The "paradise caves" discussed by Birnbaum (pp. 120-134), on the other hand, appear to be directly modeled on the Taoist grotto-heavens (see pp. 124-125).

${ }^{84}$ See Max Kaltenmark, "Chūgoku no shūkyō no shinwagaku teki ichi kenkyū: meiro to dōkutsu no tēma 中國の宗教の神話學的一研究：迷路と洞窟のテーマ," Sankō Bunka kenkyūjo nempō 三康文化研究所年報 2 (1967): 1-11 and idem, “Grottes et labyrinthes en Chine ancienne," in Yves Bonnefoy éd., Dictionnaire des mythologies et des religions (Paris: Flammarion, 1981). 
identified as the nucleus of the Lingbao scriptural revelation, in the Linwu 林屋 grotto-heaven, beneath Dongting 洞庭 (i.e., "grotto-court") Island in the Lake Taihu near Suzhou (Jiangsu). ${ }^{85}$ In Du Guangting's series of Ten Great Grotto-heavens, Linwu is no. IX; it constitutes the domain of the Elder Longwei (Longwei zhangren 龍威丈人), ${ }^{86}$ the instrument of a second "revelation" of the Five Talismans at the time of Confucius (ca. 551-471 B.C.): At the end of a dark labyrinth, we are told, winding along a distance of scveral thousand $l i$, Longwei reached a luminous city where he recovered the sacred writings hidden by $\mathrm{Yu}^{87}$

The mythological association of womb and tomb is a natural one if we regard the tomb as a place of transit and rebirth. ${ }^{88}$ The villagers taking part in the initiatory rite of the Birth Cave of Phnom Sampau described their entry into the cave as "going to die". Their reappearance is a "resurrection". ${ }^{89}$ As mentioned by Du Guangting in the preface to the Dongtian fudi yuedu mingshan $j i$ cited above, the registers of life and death were held in the grotto-heavens. The same author's tale about the transformation of the Buddhist intruder into stone cited above (p. 269) betrays a further association with the underworld: the notion that whoever partook of the food of that world remained forever bound to it-like Persephone after eating the pomegranate seed proffered by Aidoneus-corresponds to a theme from the literature about visits to the nether regions. ${ }^{90}$ Topographically, the pre-Buddhist Chinese seem to have localized the various underworld departments responsible for the processing of the souls of the dead not far beneath the actual tomb. In the wellknown story in Zuozhuan t: 傳, the future Lord Zhuang is able to circumvent his vow never to see his mother again until they met in the Yellow Springs by the

${ }^{85}$ See the detailed study of this site and its Taoist mythology in Miura Kunio 三浦國雄, Chügokujin no toposu: dōkutsu, fūsui, kochūten 中國人のトポス：洞窟、風水、臺中天 (Tōkyō: Heibonsha, 1988), pp. 113-153.

${ }^{86}$ Dongtian fudi yuedu mingshan ji $4 \mathrm{a}$.

${ }^{87}$ Max Kaltenmark, "Ling-pao: note sur un terme du taoïsme religieux," Mélanges publiés par l'Institut des Hautes Etudes Chinoises (Paris: Presses Universitaires de France, 1960), vol. 2, p. 563; Bokenkamp, "The Peach Flower Font," pp. 66-69, gives a translation of the account in Taishang lingbao wufu $x u$ 太上靃窑五符序 $(D$ 183, no. 388). On the latter, see M. Kaltenmark, "Quelques remarques sur le T'ai-chang Ling-pao wou-fu siu," Zinbun 18 (1982): 1-10. Many tales describe grottoes as places of scriptural and esoteric revelation.

${ }^{88}$ On the corresponding ritual affinity, see Arnold van Gennep, translated by Monika Vizedom and Gabrielle Caffee, The Rites of Passage (Chicago: Chicago University Press, 1960), ch. 4, 5, 8 and passim.

${ }^{89}$ Bizot, "La Grotte de la naissance," p. 233.

${ }^{90}$ For an early version of the Persephone legend, see Hymn to Demeter 370-400, Apostolos N. Athanassakis, transl., The Homeric Hymns (Baltimore and London: John Hopkins University Press, 1976), p. 12; for a Chinese example, see Hong Mai's 洪邁 (11231202) Yijian zhi 夷堅志 (Peking: Zhonghua, 1981), "Yi" 5.224-5. 
expedient of excavating a tunnel. ${ }^{91}$ The hazards of mining included accidentally breaking into these subterranean worlds. In the ninth-century story "Yin Yinke 陰䧮 客," Yin's workmen, in an attempt to sink a well, had drilled to a considerable depth when suddenly the sounds of birds and dogs were heard from the bottom of the shaft. One of the workmen lowered himself into the hole to investigate:

At first, for several tens of steps, he saw nothing and could only move forwards by groping along the wall. Suddenly after rounding a turn, he saw a brightness like the rays of the sun or the moon. He followed [the source of the light] downwards. The lower part of the cavity joined onto a mountain peak. The workman proceeded down onto this mountain. Straightening himself into an upright position, he beheld a world apart, with its own heaven and earth, sun and moon. ${ }^{92}$

The world into which Yin Yinke's workman has ascended by climbing down, crossing the threshold in Dantesque fashion head over heels, ${ }^{93}$ reveals itself to be a luminous paradise inhabited by immortals, instead of the underworld of the Long Night:

The North is the area of the Great Yin that presides over death. It is located in the deepest bottom of yang and also found deep within the earth. In Taoist cosmology, there is one long central axis between North and South, heaven and earth, above and below, which crosses the horizontal line that connects the sun and the moon. The underworld is situated at the lowest point of the earth, which however reflects the highest point of heaven and is the exact mirror image of the realms-on-high. There is an essential unity between the underworld and paradise, a unity like that which joins yin and yang. ${ }^{94}$

The cycle from birth, to rebirth, to immortality is thus encompassed in the unifying vision of the grotto as a place of passage and transcendence, the matrix of transformation.

${ }^{91}$ Zuozhuan, Yin 1. Yang Bojun 楊伯峻 ed., Chunqiu Zuozhuan zhu 春秋左傳注 (Peking: Zhonghua, 1981), pp. 14-15; translated in Burton Watson, The Tso Chuan: Selections from China's Oldest Narrative History (New York: Columbia University Press, 1989), pp. 3-4.

92 Boyi zhi 博異志, by Zheng Huangu 鄚還古 (jinshi between 806-820), (Hangzhou: Zhejiang guji, 1984 edn.), pp. 28-35. Cf. the translation and discussion in Wolfgang Bauer, China and the search for happiness, translated by Michael Shaw (New York: The Seabury Press, 1976), pp. 196-199.

93 "I raised my eyes and thought to see Lucifer as I had left him, and saw him with his legs upward-and if I became perplexed then, let the dull crowd judge who do not see what is the point that I had passed. 'Rise to your feet,' said the master..." Dante Alighieri, Divine Comedy, "Inferno," 34.88-94; Charles S. Singleton, transl., Bollingen Series 80 (Princeton: Princeton University Press, 1970), pp. 366-367.

${ }^{94}$ Isabelle Robinet, "Visualization and Ecstatic Flight in Shangqing Taoism," in Kohn and Sakade, eds., Taoist Meditation and Longevity Techniques, pp. 180-182. 
Perhaps the religious lesson implicit in the mental projection of the grottoheavens is that ultimately the quest for transcendence does not involve journeys to remote and inaccessible places; it suffices to look within, to apprehend or "recognize" the true nature, literally the "reality," of the here and the now. However, the very proximity and deceptive familiarity of this interiorized beyond also gives rise to tragic misapprehensions. I will call it the "heedless-visitor-to-paradise" theme of grotto-heaven literature: A mortal, having unwittingly stumbled into such a marvelous world promising an eternal blissful existence, finds himself drawn back to human society by human attachments (love, relations, dietary habits) ${ }^{95}$ or sheer frivolity (the ennui of timeless bliss). ${ }^{96} \mathrm{He}$ resolves to return temporarily, only to find that he has lost paradise forever. While the imaginative possibilities of this theme are exploited by some later writers of mirabilia and fiction with mundane and even humorous detachment, the following passage from the Declarations of the Perfected, set in the grotto-heaven Gouqu of Maoshan (Appendix, a, no. VIII), speaks with the seriousness of a fundamentally religious concern with human folly:

Everywhere within the Void, stone steps meander out toward the gateways, allowing free access to those coming and going, ascending and descending. None who enter and leave, walking with hurried paces, are aware that they are in the midst of a grotto-heaven. Thus they consider the route to be an exterior one! For there is nothing unusual in the light of the sun and the moon; neither are vegetation and streams in any way different from those outside. The birds in the sky criss-cross each other's paths, and the winddriven clouds form up like troops closing ranks: none of these raise any doubts either. Mysterious and unfathomable are the divine palaces that we call grotto-heavens! Beyond our powers to explain, beyond our powers to apprehend! ${ }^{97}$

What distinguishes the contemplative sage from profane humanity, in the end, is that the inner-directed vision of the former allows him to discover the essential nature or "true form" of the world he inhabits, while the latter troop in and out of paradise oblivious that, in the midst of their everyday surroundings and preoccupations, they had been momentarily poised on the threshold of the beyond.

${ }^{95}$ In the tale from Guangyi ji mentioned above (n. 8), the visitor is compelled to return by the harsh taste of his diet of roots and herbs.

${ }^{96}$ This was nearly the undoing of Young Scholar Cui 崔生 in the Qingcheng shan grotto (no. V below). See Yishi 逸史 (preface dated 847), compiled by Lu Zhao 盧㢣, ap. Taiping guangji 23.154-156, translated in F. Verellen, "Luo Gongyuan: légende et culte d'un saint taoïste." Journal Asiatique 275 (1987): 322-327.

${ }^{97}$ Zhen'gao 11.6b-7a. Soymié, "Le Lo-feou chan," p. 92, drew attention to this passage, noting its "metaphysical" tenor. See also Miura Kunio, "Dōten fukuchi," pp. 7-8. 


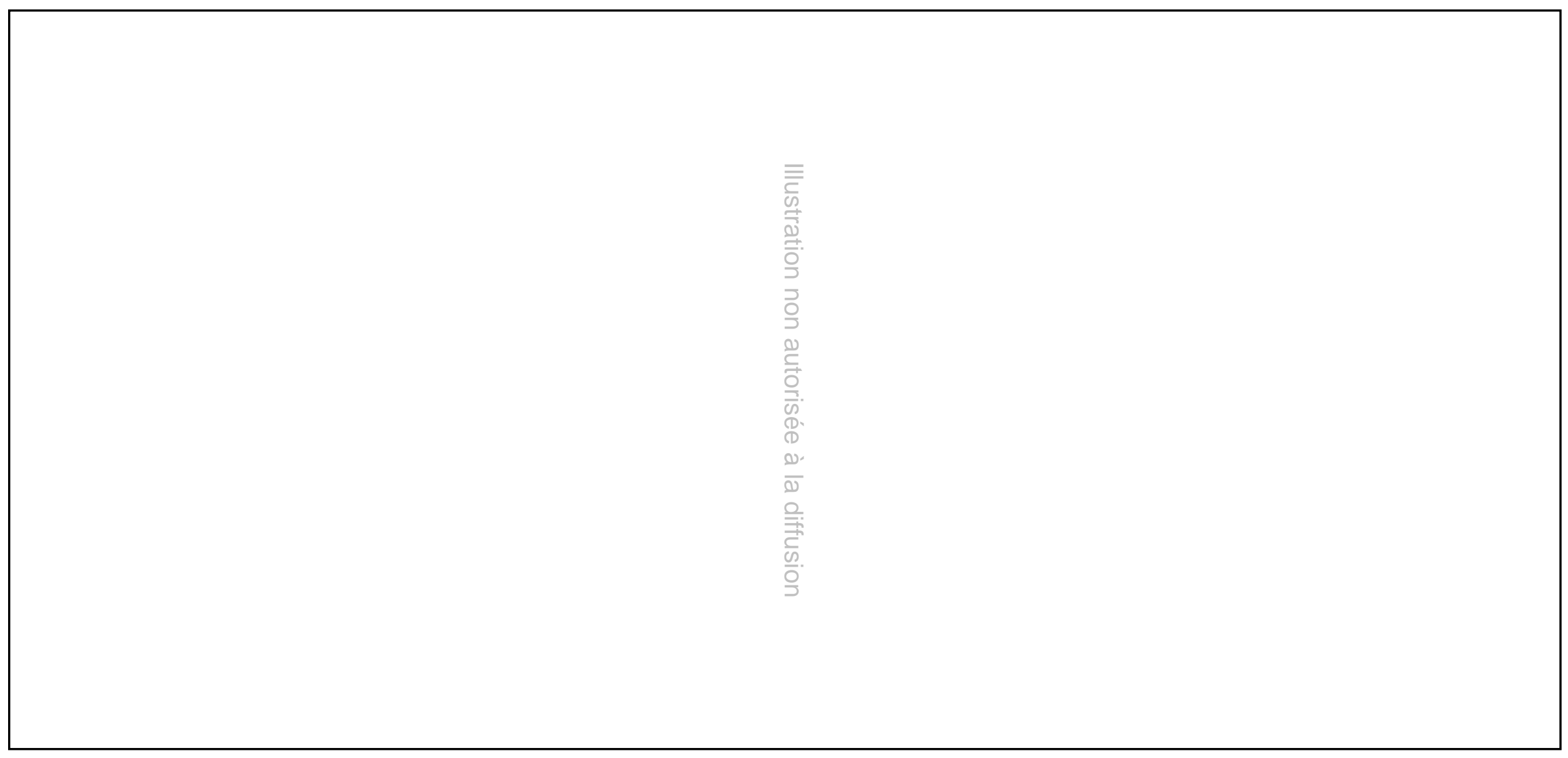

Detail from the “Outing to Zhanggong Cave 遊張公洞之圖” by Daoji 道湾 [Shitao 石濤] (1642-1707).

Photograph courtesy of the Metropolitan Museum of Art.

The Metropolitan Museum of Art, Purchase, The Dillon Fund Gift, 1982 (1982.126). 


\section{Appendix}

a. The Ten Great Grotto-heavens 十大洞天 ${ }^{98}$

\begin{tabular}{|c|c|}
\hline $\begin{array}{l}\text { I. Xiaoyou qingxu heaven 小有清虚天, Wangwu } \\
\text { grotto 王屋洞 (Jiyuan county 濟源縣, Henan) }\end{array}$ & $\begin{array}{l}\text { II. Dayou xuming heaven 大有虚明天, Weiyu } \\
\text { grotto 委羽洞 (Huangyan county 黄籍, } \\
\text { Zhejiang) (?) }\end{array}$ \\
\hline $\begin{array}{l}\text { III. Taixuan zongzhen heaven 太立總葚天, } \\
\text { Xicheng grotto 西城洞 (Ankang county 安康縣, } \\
\text { Shaanxi) }\end{array}$ & $\begin{array}{l}\text { IV. Sanyuan jizhen heaven 三元極㔬天, }{ }^{100} \\
\text { Xixuan grotto 西去洞, Huashan 華山 (Huayin } \\
\text { county 華陰縣, Shaanxi) }\end{array}$ \\
\hline $\begin{array}{l}\text { V. Baoxian jiushi heaven 仙九室天, Qing- } \\
\text { cheng grotto 青城洞 (Guan county 灌縣, } \\
\text { Sichuan) }\end{array}$ & $\begin{array}{l}\text { VI. Shangyu qingping heaven 上玉清平天, } 102 \\
\text { Chicheng grotto 赤城洞 (Tiantai county 天台縣, } \\
\text { Zhejiang) }\end{array}$ \\
\hline $\begin{array}{l}\text { VII. Zhuming yaozhen heaven 朱明曜檤天, }{ }^{103} \\
\text { Luofu grotto 羅浮洞 (Boluo county 博羅縣, } \\
\text { Guangdong) }\end{array}$ & $\begin{array}{l}\text { VIII. Jintan huayang heaven 金壇華陽天, Gouqu } \\
\text { grotto 句曲洞 [Zhong Mao peak 中茅峰] (Jurong } \\
\text { county 句容縣, Jiangsu) }\end{array}$ \\
\hline $\begin{array}{l}\text { IX. Zuoshen youxu heaven 左神幽墟天, } 104 \\
\text { Linwu grotto 林屋洞 [Mt. Dongting West 洞庭西 } \\
\text { 山] (Lake Taihu 太湖, Jiangsu) }\end{array}$ & $\begin{array}{l}\text { X. Chengde yinxuan zhen heaven 成德隐玄㣀天, } \\
\text { Guacang grotto 括荅洞 (Xianju county 仙居縣, } \\
\text { Zhejiang) }\end{array}$ \\
\hline
\end{tabular}

b. The Thirty-six [Lesser] Grotto-heavens 三十六小洞天105

\begin{tabular}{|c|c|c|}
\hline $\begin{array}{l}n \text { 霍林洞 } \\
\text { (Ningde }\end{array}$ & $\begin{array}{l}\text { 蓬玄洞天, Taishan } \\
\text { ian county 泰安縣, } \\
\text { E] }\end{array}$ & $\begin{array}{l}\text { 3. Zh } \\
\text { 衡山 } \\
\text { Hunar }\end{array}$ \\
\hline $\begin{array}{l}\text { 天, Hua- } \\
\text { unty 華陰 }\end{array}$ & $\begin{array}{l}\text { 5. Z } \\
\text { Chan } \\
\text { count }\end{array}$ & 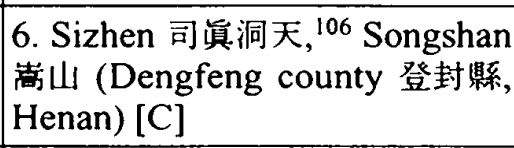 \\
\hline $\begin{array}{l}\text { 7. Xuling taimi } \\
\text { 天, Mt. Emei } \\
\text { county 峨嵋躒, S }\end{array}$ & $\begin{array}{l}\text { 8. Dongxu yongzhen 洞虛詠葚 } \\
\text { 洞天, }{ }^{107} \text { Lushan 盧山 (Xingzi } \\
\text { county 星子縣, Jiangxi) }\end{array}$ & $\begin{array}{l}\text { 9. Danshan chishui 丹山赤才 } \\
\text { Mt. Siming 四明山 (Xinc } \\
\text { county 新昌縣, Zhejiang) }\end{array}$ \\
\hline
\end{tabular}

${ }^{98}$ Dongtian fudi yuedu mingshan ji $3 \mathrm{~b}-4 \mathrm{~b}$. For an extended commentary, based on the Tushu jicheng edition of this work, see Chavannes, "Le jet des dragons," pp. 133-141.

99 On the conflicting evidence regarding this localization, see Chavannes, "Le jet des dragons," pp. 135-136.

${ }^{100}$ Sanyuan: see Tiandi gongfu tu 27.2b. Dongtian fudi yuedu mingshan ji 4a has "Sanxuan 三玄."

${ }^{101}$ For this localization, see Li Xiaoshi 李曉寅, Zhongguo daojiao dongtian fudi lansheng 中國道教洞天福地摚勝 (Hong Kong: Haifeng, 1993), p. 75. Dongtian fudi yuedu mingshan ji 4a has Jinzhou 金州 (i.e., modern Ankang; cf. IV above); Sima Chengzhen surmised that the grotto's location had not yet been discovered by humans (Tiandi gongfu tu $2 \mathrm{~b}$ ).

${ }^{102}$ Shangyu qingping: Tiandi gongfu $t u$ 3a var. "Shangqing yuping 上清玉平."

103 Yaozhen: Tiandi gongfu tu 3a var. "huizhen 輝点."

104 Zuoshen: the Tiandi gongfu $t u$ 3a var. "youshen 尤神" appears to be a graphic error.

${ }^{105}$ Dongtian fudi yuedu mingshan ji 6b-8b. Cf. Chavannes, "Le jet des dragons," pp. 141-

68. For the qualification "minor," see Tiandi gongfu $t u 3 b$.

${ }^{106}$ Sizhen: Tiandi gongfu tu 4b var. "Sima 司馬."

${ }^{107}$ Dongxu: Tiandi gongfu tu $4 \mathrm{~b}$ var. "Dongling 洞需." 


\begin{tabular}{|c|c|c|}
\hline $\begin{array}{l}\text { 10. Jixuan yangming 極玄陽明洞 } \\
\text { 天, }{ }^{108} \text { Mt. Guiji 會稽山 (Shao- } \\
\text { xing county 稆與縣, Zhejiang) }\end{array}$ & $\begin{array}{l}\text { 11. Dexuan 德玄洞天, Mt. } \\
\text { Taibo 太白山 (Zhouzhi county } \\
\text { 警椡縣, Shaanxi) }\end{array}$ & $\begin{array}{l}\text { 12. Tianbao jixuan 天窞極芝洞 } \\
\text { 天, }{ }^{110} \text { Xishan 西山 (Xinjian } \\
\text { county 新建縣, Jiangxi) }\end{array}$ \\
\hline $\begin{array}{l}\text { 13. Haosheng shangyuan 好生上 } \\
\text { 元洞天, Mt. Dawei 大圈山'111 } \\
\text { (Liuyang county 知陽縣, Hunan) }\end{array}$ & $\begin{array}{l}\text { 14. Tianzhu sixuan 天柱司去洞天, } \\
\text { Qianshan 潛山 [Tianzhu shan 天 } \\
\text { 柱山] (Qianshan county, Anhui) }\end{array}$ & $\begin{array}{l}\text { 15. Shengzhen huaxuan 昇真化玄 } \\
\text { 洞天, Mt. Wuyi 武费山 (Chongan } \\
\text { county 崇安縣, Fujian) }\end{array}$ \\
\hline $\begin{array}{l}\text { 16. Guixuan sizhen 貴玄思真洞 } \\
\text { 天, Mt. Guigu 鬼谷ll(Guiqi } \\
\text { county 貴溪縣, Jiangxi) }\end{array}$ & $\begin{array}{l}\text { 17. Rongcheng taiyu 容城太玉洞 } \\
\text { 天, Mt. Huagai 華蓋川1 (Yongjia } \\
\text { county 永嘉, Zhejiang) }\end{array}$ & $\begin{array}{l}\text { 18. Taixiu fale 太秀法樂洞天, }{ }^{114} \\
\text { Mt. Yusi 玉第 III (Xiajiang } \\
\text { county 峽江縣, Jiangxi) }\end{array}$ \\
\hline $\begin{array}{l}\text { 19. Changyao baoguang 長燿琹光 } \\
\text { 洞天, Mt. Gaizhu 蓋竹山 (Linhai } \\
\text { county 臨海縣, Zhejiang) }\end{array}$ & $\begin{array}{l}\text { 20. Taishang baoxuan 太上玄 } \\
\text { 洞 天, Duqiao shan 都崉山 } \\
\text { (Rong county 容縣, Guangxi) }\end{array}$ & $\begin{array}{l}\text { 21. Xiule changzhen 秀樂長畺 } \\
\text { 洞天, Mt. Boshi 白石山 (Gui- } \\
\text { ping county 桂平縣, Guangxi) }\end{array}$ \\
\hline $\begin{array}{l}\text { 22. Yuqu } \\
\text { 天, Mt. } \\
\text { county 北 }\end{array}$ & $\begin{array}{l}\text { 23. Xiangzhen ta } \\
\text { 天, }{ }^{115} \mathrm{Mt} \text {. Juiyi } \\
\text { yuan county 寧遠! }\end{array}$ & $\begin{array}{l}\text { 24. Don } \\
\text { 洞天, M } \\
\text { county }\end{array}$ \\
\hline 太元 & $\begin{array}{l}\text { 大酉華妙洞 } \\
\text { 11 (Yuanling } \\
\text { ) }\end{array}$ & $\begin{array}{l}\text { 27. Jint } \\
\text { 洞天, } M \\
\text { xian 睐 }\end{array}$ \\
\hline $\begin{array}{c}\text { Magu } \\
\text { 垶城 } \\
\end{array}$ & $\begin{array}{l}\text { ixian 仙都析仙洞 } \\
\text { lu 仙都山 (Jinyun } \\
\text { Zhejiang) }\end{array}$ & $\begin{array}{l}\text { 30. Qingtia } \\
\text { Mt. Qingti } \\
\text { county 青田 }\end{array}$ \\
\hline $\begin{array}{l}\text { 大涤立蓋洞天, } \\
\text { 主.山 (Lin'an } \\
\text { 'hejiang) }\end{array}$ & $\begin{array}{l}\text { 32. Zhuhu taisheng 朱湖太牛洞 } \\
\text { 天, Zhongshan 鐘山 (Nanjing } \\
\text { 南京市, Jiangsu) }\end{array}$ & $\begin{array}{l}\text { 33. Liangchang } \\
\text { 洞 天, Mt. Lian } \\
\text { (Jurong county }\end{array}$ \\
\hline $\begin{array}{l}\text { gguang 向馬玄光洞 } \\
\text { n 挑源山 (Taoyuan } \\
\text { Hunan) }\end{array}$ & $\begin{array}{l}\text { 35. Jinhua dongyuan 金華洞元 } \\
\text { 洞天, Mt. Jinhua 金華山 (Jinhua } \\
\text { 金華市, Zhejiang) }\end{array}$ & $\begin{array}{l}\text { 36. Zixuan dongmeng } \\
\text { 洞天, Mt. Zigai 紫蓋山 (D } \\
\text { yang county 當陽影系, Hubei) }\end{array}$ \\
\hline
\end{tabular}

108 Yangming: Tiandi gongfu $t u 4 \mathrm{~b}$ var. "Dayuan 大元." According the latter, this grottoheaven is located in the Mirror Lake (Jinghu 鏡湖, in modern Shaoxing).

${ }^{109}$ Taibo: Dongtian fudi yuedu mingshan ji 7 a reads "Fangbo 方白."

110 Tianbao: Tiandi gongfu tu 5a var. "Tianzhu 柱 bao."

"II Shangyuan: Tiandi gongfu tu 5b var. "Xuanshang 䒺上”; Dawei: ibid., var. "Xiaowei 小鸴."

112 The grotto-heavens no. 15 and 16 appear in reversed order in Tiandi gongfu tu 5b-6a.

Shengzhen: ibid., var. Zhensheng.

113 Nos. 17 and 18 appear in reversed order in Tiandi gongfu tu 6a-b.

114 Taixiu: Tiandi gongfu tu 6a var. "Taixuan 太立."

115 Xiangzhen: Tiandi gongfu tu 7a var. "Chaozhen 朝蒠."

116 Li Xiaoshi, Dongtian fudi lansheng, p. 169, erroneously identifies this with another place of the same name in Chao county 果縣, Anhui. Cf. Tiandi gongfu tu $7 \mathrm{~b}$ and Chavannes, "Le jet des dragons," p. 161.

117 Tiandi gongfu tu $8 \mathrm{~b}$ lists this grotto as no. 34, “Tiangai dixuan 天蓋條玄," of “Tianmu 日 shan." For a peak of that name in the range in question, see Dadi dongtian ji 大滌洞天記, by Deng Mu 鄧牧 (1247-1306), D 559, no. 782, B.1b-2a. Chavannes considered that the grotto was situated in neighboring Mt. Dadi ("Le jet des dragons," p. 164).

${ }^{118}$ No. 31 in Tiandi gongfu tu 8a, Var. "Zhuri 1 taisheng."

119 Adjacent to Xiao Mao peak 小茅峰, in the north-eastern part of the Maoshan range. See Li Xiaoshi, Dongtian fudi lansheng, p. 40. No. 32 in Tiandi gongfu tu 8 b.

${ }^{120}$ No. 35 in Tiandi gongfu $t u 9$ a.

121 No. 36 in Tiandi gongfu $t u 9$ a.

122 No. 33 in Tiandi gongfu tu 8b. Dongtian fudi yuedu mingshan ji $8 \mathrm{~b}$ erroneously places Mt. Zigai in Qujiang county 曲江縣 (Guangdong). Cf. Li Xiaoshi, Dongtian fudi lansheng, p. 183; Chavannes, "Le jet des dragons," pp. 167-168. 